\title{
Patterns of the Social Economic Society of Fishermen Communities in Bantaya Village, Parigi Moutong District, Indonesia
}

\author{
Mohammad Tofan Samudin ${ }^{1 *}$, Sulaiman Mamar $^{2}$, Hasan Muhammad ${ }^{2}$, Rosmawati $^{2}$ \\ ${ }^{1}$ Lecturer in Sociology at the Faculty of Social and Political Sciences Universitas Muhammadiyah Palu, \\ Indonesia \\ ${ }^{2}$ Universitas Tadulako, Indonesia
}

*Corresponding Author: Mohammad Tofan Samudin, Lecturer in Sociology at the Faculty of Social and Political SciencesUniversitas Muhammadiyah Palu, Indonesia

\begin{abstract}
This study aims to look at how the pattern of socioeconomic life of the fishing community groups what factors are inhibiting the fishing community groups in Parigi Moutong Regency in carrying out their activities. This research is a qualitative descriptive study, a research that aims to provide a descriptive analysis of the object under study. Data. Presentation of data is a collection of structured information that gives the possibility of making conclusions. This happens because with the presentation of data will be understood what is happening. This study concludes that the pattern of socioeconomic activities of the floating community in Bantaya Village in general has no difference with the socio-economic activities of the fishing communities in other areas, namely individual service activities and some groups. In the intended group activity, everyone has their respective roles and functions. Some act as owners of capital and owners of tools in the group.
\end{abstract}

Keywords: Patterns of Social Economy Activities of Fishermen Communities

\section{INTRODUCTION}

Two-thirds of the territory of Indonesia is a sea that holds a lot of wealth, especially fish that are consumed daily by residents of this country. Legally exported even in the loot or illegally explored by a number of foreign fishermen. At least 3.2 million households or 16 million people in Indonesia work as fishermen, but $70 \%$ or around 11.2 million are classified as poor people [1].

Central Sulawesi has seawater sources, it is estimated that the waters are around 3 times the land area of 193,923, $75 \mathrm{~km} 2$ stretching along the eastern region as far as Tolo Bay and Tomini Bay and the west is the Makassar Strait and part of the Sulawesi Sea. Potential marine waters contain a very large source of income in the form of fish food ingredients and marine plants. The potential of marine waters in Central Sulawesi is estimated at 1,593,796 tons per year. From the maritime and fisheries sector has enormous potential because of the vast sea waters. Management of this potential is expected to create a fishery-based industry that will grow and develop to increase added value. Main commodities that can be developed from the marine and fisheries sector include shrimp, tuna, skipjack, grouper, sea cucumbers, single and tilapia [2].

Problems or strategic issues that arise in the development of leading commodities in the fisheries sector are inadequate facilities and infrastructure, lack of availability of ocean fishing ports, insufficient electricity for cold storage, road conditions to inadequate production centers and airports not yet direct exports, need to increase knowledge and skills of catching human resources for the capture and processing of fishery products. Fishermen do not have adequate fishing facilities [3].

In line with the strategic issues above, the Central Sulawesi regional government established policies related to the development of leading commodities in the fisheries sector, including policies for developing coastal areas and marine potential. In order to implement the policy and address strategic issues and issues regarding the development of capture fisheries, various development programs and activities consisting of core and supporting programs need to be developed. 
As has been said before that Parigi Moutong Regency is one of the regencies that has a large potential of marine resources (fish and others) and can be utilized for the development and improvement of the welfare of the community's life, especially the fishing community itself, bearing in mind the fishing community to date this is still shrouded in poor life, so it needs to be maximally empowered through the utilization of available marine resources [4].

The target of this research is capture fishermen in Bantaya Tanjung Village, Parigi District, Parigi Moutong Regency. Most of the villagers work as fishermen with various service activities, such as fishing fishermen, trawlers, and others. Their ability to utilize fishermen's activities to the fullest is very possible because in addition to the very promising potential of marine resources, a fisherman can also perform various other fishing activities. Because if a fisherman only does one type of fishing activity such as fishing while this activity can only be done in 15 to 18 days a month and lasts only from January to July of the current year, then their income will be limited. So they make use of the free time gap by doing other fishing activities to supplement their income. If they do not take advantage of the free time, it means there is no income. Then that's when fishermen will do debt receivables in meeting their daily needs. Especially if they deal with middlemen, then poverty will continue to be friendly with the fishermen.

This study aims to see how the pattern of socio-economic life of the fishing community groups what factors are inhibiting the fishing community groups in Parigi Moutong Regency in carrying out their activities.

\section{Materials AND Methods}

This research is a qualitative descriptive study, a research that aims to provide a descriptive analysis of the object under study. In this study using qualitative data analysis techniques which include the following stages: (1) Data Reduction. Data Reduction is defined as the process of selecting, focusing on simplifying, abstracting and transforming rough data arising from field notes. Data reduction is part of data collection activities which are also part of the analysis. Data reduction is a form of analysis aimed at sharpening, classifying, removing unnecessary; (2) Data Display (Data Presentation. Data presentation is a collection of structured information that gives the possibility of making conclusions. This happens because the presentation of data will be able to understand what is happening and what should be done based on that understanding; (3) Conclusion Drawing / verivication: Drawing conclusions and verifying, that is, the meaning-eating that appears in the data must be tested for its truth, its robustness and compatibility, that is its validity.

\section{RESUltS AND DISCUSSION}

\subsection{Patterns of Social Economic Activities of Fishing Communities}

Most social categories of Indonesian fishermen are traditional fishermen and labor fishermen. They are the main contributor to the quantity of national capture fisheries production. The archipelago's marine area is vast and contains a variety of potential resources, including fisheries. All of that will become a source of future livelihood if utilized optimally and preserved. The fishing community that lives and seeks the sea of the archipelago is an integral part that must participate in it, especially in the participation of filling the interests of the people at any time. [5].

Fishermen who are sometimes positioned only as workers at sea have been operated as not having significant ability to fill the nation's empowerment, various doubts about the expertise of fishermen that are not actually possessed by other communities. Though the specific expertise of these fishermen is a cooperative advantage possessed by this nation [6]. Therefore fishermen are actually the main trigger for the success of marine development.

The fishing profession is a profession that is quite old on this earth and has been cultivated by generations of people for generations, especially for people who live around the coast. The fishing profession is not a profession that is easily cultivated by just anyone [7]. Although this work does not require special skills that must be obtained through formal education. Work as a fisherman is a difficult but exciting job for the workers. A job as a fisherman is full of challenges, full of risks and sometimes lives are at stake [8]. 
Working as a fisherman there is almost no time and space limit because the vast ocean that is almost endless is an arena or area to look for wealth in it. The sea is a hunting ground. Anyone has the right to try his luck and take advantage of the contents in it. No one can claim that this sea is its territory except the territorial zone boundaries that have been established by the state and have become an agreement on International Sea Law agreed by the United Nations in 1982. The Territorial Sea Zone is an imaginary line within 12 nautical miles from base line towards the high seas.

The author begins a search of 10 fishermen as respondents interviewed by asking the length of time they were fishermen, obtained quite diverse data that is, they became fishermen from 5 years to over 15 years ago. More details about the data in question, can be seen in the following table:

Table1: The length of time fishermen have worked in their profession

\begin{tabular}{|l|l|l|l|}
\hline No & \multicolumn{1}{|c|}{ Indicator } & \multicolumn{1}{c|}{$\mathbf{1}$} & \multicolumn{1}{c|}{$\%$} \\
\hline 1 & 5 years & 1 & 10 \\
\hline 2 & 5-10 years & 3 & 30 \\
\hline 3 & More than 15 years & 6 & 60 \\
\hline & Amount & $\mathbf{1 0}$ & $\mathbf{1 0 0 \%}$ \\
\hline
\end{tabular}

Source: Primary Data 2018

The results of the research outlined in the above table explain that it turns out that most of the fishermen have worked as fishermen more than 15 years ago. The data was obtained from $6(60 \%)$ respondents. This respondent acknowledged that working as a fisherman in Bantaya Village is a job that has been passed down through generations. Starting from grandmother, then down to the father, then to the child. There is hardly any other kind of exciting job in Bantaya Village aside from being a fisherman. Although working as a fisherman is not the only job in the village of Bantaya, the work as a fisherman has been a work that is occupied even as the foundation of family life for decades, because this job as a fisherman may be difficult to let go at any time.

Meanwhile as many as 3 respondents (30\%) who said that they became fishermen approximately 5 to ten years ago. This respondent also has a reason to be a fisherman. Among other things, it was explained that their participation in becoming fishermen was the encouragement and motivation of the family who had first been engaged in the work. Their predecessors have proven that working as a fisherman is very suitable to be occupied in the village of Bantaya, the natural wealth of the sea in it will never run out forever.

Then as many as 1 respondent who said that his job as a fisherman was occupied since 5 years ago. This respondent said that there was no other choice but to be a fisherman. Moreover, he claimed to be a derivative who was a fisherman. He has no other skills besides being a fisherman who has been handed down from his family.

Thus the respondents become fishermen in the village of Bantaya differ in the length of time they pursue their work as fishermen. But it has the same goal which is to meet the needs of his life and his family.

It turns out that besides being a fisherman there are also those who have side jobs as explained by one of the respondents (salman $35 \mathrm{yrs}$ ) He said that working as a fisherman cannot be done every day, it cannot be done for one full month, for example 15 days to 20 days. After all, most fishing activities are carried out at night, so that during the day it can be used to find additional work. In addition, during the big waves, strong wind season is not possible to go down to sea. Not to mention if there is equipment that is damaged, the need for time to repair or maintenance at that time fishermen do not go down to sea. So clearly there are certain times that can be used to find additional work. It turns out that this respondent's side job is as a construction worker who has a decent income.

Side jobs like this clearly provide additional income for the fishermen themselves. Respondents acknowledge that work as fishermen remains a main job (main) that they are unlikely to leave, but side jobs are also very important, especially if the side work is not sought but managed by themselves such as opening a kiosk at home that sells various community needs, especially daily needs day including the needs of the fishermen themselves such as food. 
The social and economic life of fishing communities basically cannot be discussed separately from the everyday social realities that appear around them. As a fishing community even though those who are struggling daily with the ferocious waves that are sometimes accompanied by heavy rain or scorching sun, but that does not mean that their social life is depicted as a hard social life [9]. Fishing communities are ordinary people whose daily lives are the same as the community in general. They still need other humans around them, whether it is fellow fishing communities or with people who have other professions that live side by side.

Humans cannot live alone without help from other humans. One way for humans to fulfill their daily needs is both personally and as social beings by collaborating. Cooperation is an activity or business carried out by two or more people to achieve a common goal [10].

The following table is the results of researchers' interviews with respondents about the collaboration that exists in people's daily lives.

Table2: Community Cooperation in Bantaya Village

\begin{tabular}{|l|l|l|l|}
\hline No & \multicolumn{1}{|c|}{ Indication } & \multicolumn{1}{|c|}{ Respondents' Answers } & \multicolumn{1}{c|}{$\%$} \\
\hline 1 & Urgent & 8 & 80 \\
\hline 2 & Not important & 1 & 10 \\
\hline 3 & significant & 1 & 10 \\
\hline & Total & $\mathbf{1 0}$ & $\mathbf{1 0 0 \%}$ \\
\hline
\end{tabular}

Source: Primary Data 2018

From the table above there are 8 respondents $(80 \%)$ who stated that cooperation was important in their daily lives. The people of Bantaya Village provide support for their participation in carrying out daily activities in terms of meeting their daily needs.

Meanwhile there is 1 respondent who considers that cooperation is not important. Respond to give reasons, for what cooperation if it can be done alone. And no more expenses. The community further explained that the work in this village was carried out together before the work was carried out at sea. They already have working groups together to go to sea if it is determined.

Some fishermen in Bantaya village are done individually and some are done in groups, each member having their respective roles. There is a role as the owner of the tool, the owner of capital (skipper) and also as subordinates or ordinary members. The data can be seen in the following table:

Table3: The role of each member of the fishing group

\begin{tabular}{|l|l|l|l|}
\hline No & \multicolumn{1}{|c|}{ Respondents' Answers } & \multicolumn{1}{c|}{ f } & \multicolumn{1}{c|}{$\%$} \\
\hline 1 & As a tool owner & 2 & 20 \\
\hline 2 & As a Capital Owner & 2 & 20 \\
\hline 3 & As a member / subordinate & 6 & 60 \\
\hline & amount & $\mathbf{1 0}$ & $\mathbf{1 0 0}$ \\
\hline
\end{tabular}

Source: Primary Data 2018

It turned out that the respondents surveyed, mostly only as members or subordinates in group fishing activities. The data was obtained from as many as 6 respondents $(60 \%)$. Furthermore, this respondent gave a statement that to become a fisherman who owns capital or owns the equipment, is still difficult because it requires a large enough cost, so that only certain people can have it.

Then 2 respondents (20\%) who said they were owners of the equipment. The owner of the equipment in question is like the owner of the boat / ship, the owner of the electric engine used at night, the owner of the fishing gear and the like. . And 2 more respondents (20\%) who declared themselves as owners of capital. The capital in question is the costs that must be incurred when going to sea, such as the costs required to buy kerosene, gasoline, consumption costs during the sea, including cigarette money, coffee, tea, and the like. However such needs absolutely must be present in the process of carrying out the task. The fishermen consider that such needs when they are at sea become additional energy, especially working at night with uncertain weather and air, sometimes rain, cold, strong winds, so they need extra power. 
Thus it can be seen that each group of fishermen each has a level of role when they are at sea to look for fish, which is of course also the distribution of the results of the catches are divided based on their role.

In contrast to individual fishermen, there is no distribution of results because there are no other workers except himself, so the results obtained are not shared, it is up to them to sell if possible or want to be consumed alone. Fishermen in the village of Bantaya do not have to go down to sea every day, because there are certain times that do not go down to sea at all, such as during high wind season, big wave season.

In Bantaya Village there is no visible competition, let alone what is said to be competitive, even though the competition is still there. According to one respondent that competition, especially among fishing communities, is almost invisible. This means that efforts to maximize productivity have not been carried out by the fishing communities in the village. Whereas competition is very important as one of the motivations in efforts to improve the quality and quantity of production (Catches). The author's observations show that the visible form of competition is in the form of competition in marketing the catch, especially if the catch is in the form of fish that have high economic value such as type of stone fish. They know the price of fish is expensive, so sometimes they are waiting for buyers who come from outside the city such as from Palu City so that the value or price can be higher.

The absence of competitive competition in community service activities in the Village of Bantaya, the authors conclude that this is one of the causes of the increase in production (catch) so that the income of the community in the Village of Bantaya is still low.

\subsection{The Economic Life of the Bantaya Village Fishermen Community}

The economic life of the people of Bantaya Village can be said to be inadequate let alone profitable. According to the data obtained on average from respondents admitted that it is still very limited, both in terms of the number of catches and the price of the catch which is one of the parameters in viewing their income level. Most of their catches have not been able to meet the needs of daily life, especially for fishermen who have a large number of family dependents (children), of course, really feel that life is still barely mediocre. The proceeds from the sale of fish are mostly used to buy daily needs.

Most of the fishermen in Bantaya Village have not been able to meet the primary needs to the full, let alone secondary needs. Nevertheless, their social position remains marginal in the process of economic transactions which are lame and exploitative so that as producers, fishermen do not get a large share of income. The luckiest parties are large-scale fish traders or intermediary traders. These traders actually became the economic rulers in the village of Bantaya. In addition, there are still brokers who contribute to the burdens of the fishermen in Bantaya Village. This condition continues to happen to fishermen without having to know how to end it. This has given rise to a number of crucial socioeconomic problems in fishing communities. When they have to go to sea, fishermen borrow money from middlemen, when they return from fishing, the results of the fishing they get are given to the middlemen to pay off their debts, so that the rest of the catch is then sold to earn money to make ends meet.

When viewed from the average level of income of fishermen in each month if measured in rupiah is actually quite adequate. But that is still a gross matter, they still have to spend the operational costs that are used for fishing. The following table is the average income of fishermen in Bantaya Village, as follows:

Table4: Average income of Bantaya Village Fishermen

\begin{tabular}{|l|l|l|l|}
\hline \multicolumn{1}{|c|}{ No } & \multicolumn{1}{|c|}{ Income level (IDR) } & \multicolumn{1}{c|}{$\mathbf{f}$} & \multicolumn{1}{c|}{$\%$} \\
\hline 1 & $250.000-500.000$ & 3 & 30 \\
\hline 2 & $500.000-750.000$ & 3 & 30 \\
\hline 3 & $750.000-1.000 .000$ & 2 & 20 \\
\hline 4 & $>1.000 .000$ & 2 & 20 \\
\hline & amount & $\mathbf{1 0}$ & $\mathbf{1 0 0 \%}$ \\
\hline
\end{tabular}

Source: Primary Data 2018 
The table data above is the income data of fishermen who are still dirty, because of that income there are still costs to be incurred. For example fuel costs for fishing boat engines, engine maintenance costs if there is damage and consumption. All that is a fixed cost that must be incurred every time you go to sea.

Of the 10 respondents interviewed, those earning between Rp 500,000 - Rp 750,000 every month were 3 respondents or $30 \%$ then 1 respondent or $10 \%$ earned Rp 250,000 - Rp 500,000 every month. Specifically the 3 respondents in conducting their activities at sea only used boats without engines, so their reach was very limited. While respondents who earn Rp. 750,000 - Rp. 1,000,000 per month and who earn an average of Rp. 1,000,000 / month only have 2 people each. This respondent is a respondent who has a motor boat that has a far enough reach, even to the island of Makatata which is directly opposite the Parigi Moutong Regency.

By looking at the economic conditions of fishermen in Bantaya Village like this, it is illustrated that economically the Fishermen community in Bantaya Village is still classified as poor fishermen. However, structural shackles in fishing activities are not the only factors that cause social problems among fishermen, other factors are synergies, such as the increasing scarcity of fisheries resources, damage to coastal and marine ecosystems, and limited quality and capacity of fishing technology, the low quality of human resources, unequal access to fisheries resources, as well as weak policy protection and support for development facilities for fishing communities are still factors that cause problems. Deteriorating social welfare conditions among fishermen are strongly felt in coastal villages where the waters are overfishing so that the catch or income obtained by fishermen is fluctuating, uncertain, and declining over time. In such a situation, fisherman households will always be faced with three crucial problems in their lives, namely: (1) struggles to meet their daily needs, (2) faltering in fulfilling the educational needs of their children, and (3) their limited access to health insurance. The three accesses above are the most basic necessities of life in a fishing household, which are often not optimally fulfilled. With such realities of life, it is very difficult to formulate and build the quality of fishermen community resources, so that they have the optimal ability to manage the potential of existing coastal coastal resources.

\subsection{The Social Life of the Fishermen of the Bantaya Village}

The potential of marine resources owned by Tomini Bay waters is very abundant. It is unfortunate if its utilization cannot be carried out to the maximum. Bantaya Village fishermen can put greater hope on the marine resources owned by the waters of Tomini Bay.

With reference to the availability of existing marine resources, according to the author, in terms of the social life of the fishing community economy in Bantaya Village, of course it will be in a good and favorable condition, there will be no social problems that cause things that are not beneficial like the problem of poverty [11].

Looking at the geographical location of the Bantaya village into the capital region of Parigi Moutong Regency, it is not impossible that Parigi Moutong Regency can make the marine sector an important sector in regional development. As a form of supporting government programs to make the fisheries sector a leading sector of the national economy. For this reason, the potential that exists in the sea around Bantaya Village must be utilized optimally and sustainably, this task is a joint responsibility of the government, the community and entrepreneurs in order to increase community income and regional revenue that leads to people's welfare.

The sustainable potential of Indonesia's marine fish resources of 6.5 million tons per year is scattered in the territorial waters of Indonesia and the waters of the Indonesian Exclusive Economic Zone (EEZ) which is divided into nine major waters areas of Indonesia. Of all the potential resources, in order to maintain the sustainability of fish stocks the number of allowed catches (JTB) is 5.12 million tons per year.

Bantaya Village is the most populous village compared to other villages in Parigi District. The native tribe of the Bantaya village community is the Kaili tribe. However, the data obtained by the writer in the research location is that some of the fishing communities that live in Bantaya Village are also from Gorontalo and Bugis. Ethnic diversity found in Bantaya Village does not make any difference between the people in Bantaya Village. Precisely with the diversity of tribes to make people gain experience and knowledge in daily activities that have one goal, namely to improve family welfare by utilizing available marine resources. 


\subsection{Supporting and Inhibiting Factors in Efforts to Improve the Socio-Economic Life of Fishing Communities}

The absence or lack of creative ability of fishing communities to overcome the socioeconomic areas in their area will push them into a prolonged set of backwardness that can interfere with the achievement of development policy goals in the marine and fisheries sector. For this reason, alternative strategy solutions need to be considered to address the socio-economic life problems faced by fishing communities. In this case, a social security program that is formally designed is one of the strategies that should be considered to overcome the socio-economic turmoil that afflicts the lives of fishing communities [12]. Even though the state or government has implemented a number of policies to develop the capture fisheries sector and productive economic empowerment in order to improve the welfare of fishermen, the results achieved are still not optimal. If we pay attention, so far the spirit of national policy in the development of fisheries since the early 1970s and is still being applied today which prioritizes increased production, resulting in scarcity of fisheries resources, damage to coastal marine ecosystems, poverty, and social inequality. Such a policy is not accompanied or guarded by a comparative policy on how the fishing community must maintain the sustainability of marine resources. Actually, this policy provides economic benefits for fishermen with large capital that are quantitatively few in number, but in the end all fishermen from various business categories face the same problem. Likewise, the economic empowerment policy of the fishing community that has been applied so far. If it is analogous to fishing people, the policy only gives fish to fishermen, but does not provide a guarantee of sustainability if how the fishing gear is damaged. This can be demonstrated by the weak support of the policies of official banking institutions for lending with low interest to the fishing community in a sustainable and consistent manner. [13].

Basically, this support is needed by fishermen to maintain the continuation of their fishing business. The fluctual symptoms above reflect the absence of an umbrella policy on empowerment that is national in nature and becomes a reference for decision makers at ministerial level so that it provides a sense of security for banking institutions to work with fishermen in credit assistance transactions. In addition, the absence of parties who help totally and seriously in developing a fishing community, encourages the fishing community to develop an independent strategy based on the ability of the resources they have to solve the various problems they face. This independence generates autonomous attitudes among fishermen. Valuable social capital as a basis for their survival. Manifestation of the autonomous attitudes of fishermen manifested in the construction of social institutions, such as savings and loan associations, social gathering, and social networks function to mobilize the ability of collective economic resources in reciprocal relations so that the existence of the fishing community remains guaranteed.

According to the fishermen's confession, this factor is felt as an inhibiting factor in efforts to improve their economic life.

The following are the results of the author's interview with fishermen regarding this inhibiting factor:

"We who work as fishermen by using dinghy boats that rely on human power (rowing) actually include fishermen who are very difficult to improve their lives better than now, even more backward if they are not immediately replaced by motorbikes. Because the boat that I used is old, this is help from the government that was received 5 years ago, only paint it, while I can't save to buy a new boat. Then my energy has diminished because I am 57 years old. I could no longer paddle any further. Meanwhile, to get a lot of fish it must be to the middle of the sea. Not to mention if the weather suddenly changes. If it's like that, the only way to return. Usually when the wave season, I can not go to sea. This is the reason why fishermen like us cannot improve their lives better ". (Mr. Suardin, 57 years old).

Meanwhile, other respondents also acknowledged that the biggest inhibiting factor was climate change, which suddenly occurred when fishermen were in the middle of the sea. If the weather changes come before they go to sea, they can anticipate by delaying their fishing activities for a while. But often the weather changes come when fishermen are in the ocean. At that time what they were thinking about was how to save themselves.

From the description above it can be seen that in the Bantaya Village fishermen there are still very large obstacles that must be faced. If these inhibiting factors cannot be overcome, of course the logical consequence is that fishermen will continue to live in a disadvantageous life because they cannot 
improve welfare. Although the supporting factors are also very much available to carry out fishing activities, but the supporting factors will not be maximally utilized if the inhibiting factors have not been found to be resolved. For example, one of the supporting factors is the availability of abundant marine resource potential, but if the equipment used is still limited or still traditional, then fishermen will not be able to get results that are also in abundance. And it is unfortunate, the sea around Bantaya Village which has abundant marine resource potential but its management has not been maximized.

\section{CONCLuSiOnS}

Based on the results of the research that has been parsed, the authors then make some conclusions, that the pattern of socioeconomic activities of the nelayang community in Bantaya Village in general has no difference with the socio-economic activities of fishing communities in other areas, namely service activities carried out individually and there are also in groups. In the intended group activity, everyone has their respective roles and functions. Some act as owners of capital and owners of tools in the group. And some are individuals, doing their own service activities. In addition, in pursuing his profession as a fisherman, the fishing community of Bantaya Village is always confronted with various factors that hinder their activities. The inhibiting factors include: first; fishermen community resources are relatively low, so that it affects the ability to explore marine resources, second; unable to establish or increase working capital because they do not have access to financial institutions guaranteed by the state (banking), so that fishermen take shortcuts to deal with middlemen. As a result, fishermen can only dig holes, close the holes. Could not improve the welfare of his family. The equipment that is owned is fairly old and sufficient capital.

\section{REFERENCES}

[1] Kementerian Kelautan dan Perikanan, "Marine and Fisheries Information," Kementeri. Kelaut. dan Perikan., 2016.

[2] D. J. Tarigan, D. Simbolon, and B. Wiryawan, "STRATEGY FOR OUR FISHERIES MANAGEMENT IN BANGGAI LAUT REGENCY, CENTRAL SULAWESI PROVINCE,” J. Teknol. Perikan. dan Kelaut., 2019.

[3] E. Retnowati, "FISHERMEN INDONESIA IN STRUCTURAL POVERTY CIRCLE (SOCIAL, ECONOMIC AND LEGAL PERSPECTIVE)," Perspektif, 2011.

[4] E. Jokolelono, "Food and Food Availability," Media Litbang Sulteng, 2011.

[5] S. Busilacchi, G. R. Russ, A. J. Williams, S. G. Sutton, and G. A. Begg, "The role of subsistence fishing in the hybrid economy of an indigenous community," Mar. Policy, 2013.

[6] M. B. Mascia, C. A. Claus, and R. Naidoo, "Impacts of marine protected areas on fishing communities," Conserv. Biol., 2010.

[7] N. S. Jacobsen, H. Gislason, and K. H. Andersen, "The consequences of balanced harvesting of fish communities," Proc. R. Soc. B Biol. Sci., 2013.

[8] G. Bianchi et al., "Impact of fishing on size composition and diversity of demersal fish communities," in ICES Journal of Marine Science, 2000.

[9] A. Himes-Cornell and S. Kasperski, "Assessing climate change vulnerability in Alaska's fishing communities," Fish. Res., 2015.

[10] G. Bwire et al., "Epidemiology of cholera outbreaks and socio-economic characteristics of the communities in the fishing villages of Uganda: 2011-2015," PLoS Negl. Trop. Dis., 2017.

[11] J. Urquhart and T. G. Acott, "Re-connecting and embedding food in place: Rural development and inshore fisheries in Cornwall, UK," J. Rural Stud., 2013.

[12] T. R. Mcclanahan and C. C. Hicks, "Changes in life history and ecological characteristics of coral reef fish catch composition with increasing fishery management," Fish. Manag. Ecol., 2011.

[13] S. Senapati and V. Gupta, "Socio-economic vulnerability due to climate change: Deriving indicators for fishing communities in Mumbai," Mar. Policy, 2017.

Citation: Mohammad Tofan Samudin, et.al. "Patterns of the Social Economic Society of Fishermen Communities in Bantaya Village, Parigi Moutong District, Indonesia". International Journal of Humanities Social Sciences and Education (IJHSSE), vol. 6, no.9, 2019, pp. 126-133. doi: http://dx. doi.org/10.20431/234 9-0381.0609014.

Copyright: () 2019 Authors. This is an open-access article distributed under the terms of the Creative Commons Attribution License, which permits unrestricted use, distribution, and reproduction in any medium, provided the original author and source are credited. 